\title{
Is philosophy of education a historical mistake? Connecting philosophy and education differently
}

Theory and Research in Education 2014, Vol. I2(I) 65-76

(C) The Author(s) 2014

Reprints and permissions: sagepub.co.uk/journalsPermissions.nav DOI: I0.1 I77/I4778785I35I7338 tre.sagepub.com

\section{Gert Biesta}

University of Luxembourg, Luxembourg

\begin{abstract}
In this article, I suggest that the question whether the proper place for philosophy of education is in the domain of philosophy or the domain of education cannot be resolved as long as we think of the connection between philosophy and education in terms of the idea of 'philosophy of education'. To substantiate this point, I look into the history of the idea of 'philosophy of education', both as a general idea and with regard to the way in which it became institutionalised in universities in the English-speaking world. I contrast this with the way in which the academic study of education developed in German-speaking countries in order to highlight that 'philosophy of education' is not the only way in which philosophy and education can be connected. Being aware that the connection between philosophy and education can be made differently not only provides a way out of the discussion about the proper identity and location of philosophy of education, but also hints at forms of philosophically informed scholarship that are more firmly based with the academic field of education rather than that they remain a halfway house in between philosophy and education.
\end{abstract}

\section{Keywords}

Academic disciplines, education, history of education, 'Pädagogik', philosophy, philosophy of education, teacher education

\section{Introduction}

In this article, which is written in response to John White's essay 'Philosophy, Philosophy of Education, and Economic Realities', I seek to make a simple point, which is that the

\section{Corresponding author:}

Gert Biesta, Institute of Education and Society, University of Luxembourg, Campus Walferdange, Route de Diekirich, L-7220, Walferdange, Luxembourg.

Email: gert.biesta@uni.lu 
question whether the proper place for philosophy of education is in the domain of philosophy or the domain of education cannot be resolved as long as we think of the connection between philosophy and education in terms of the idea of 'philosophy of education'. To substantiate this point, I look into the history of the idea of 'philosophy of education', both as a general idea and with regard to the way in which it became institutionalised in universities in the English-speaking world. I contrast this with the way in which the academic study of education developed in German-speaking countries in order to highlight that 'philosophy of education' is not the only way in which philosophy and education can be connected. My ambition with this exercise is neither to criticise the idea of "philosophy of education' nor to question its existence, but rather to show that the two fields can be connected differently and have been connected differently. While such a different connection is not without problems itself, being aware of it may at least help to put the ongoing discussion about the proper location and identity of philosophy of education into a wider context.

\section{Location, location, location}

In his essay, 'Philosophy, Philosophy of Education, and Economic Realities', John White raises a number of pertinent questions about the state and status of philosophy of education and about its possible role in a rapidly changing global economy. White's argument moves from a discussion about the nature of philosophy of education, via a discussion of a number of essays in the recent published Oxford Handbook of Philosophy of Education (Siegel, 2009) - focusing specifically on the contribution by Philip Kitcher on 'Education, Democracy and Capitalism' - to an analysis of shifts in the global economy, in order to arrive at an agenda for education within which he articulates a particular role for philosophy of education.

I share many of White's sentiments. At a general level, I agree with his views on the place and identity of philosophy of education, albeit that I wish to introduce some refinements (see below). I sympathise with his wider political outlook about the kind of society he sees as the more desirable one - a position which I would characterise as liberaldemocratic with a socialist 'twist' (or, for UK readers: more 'old Labour' than 'new Labour'). I am slightly more puzzled about his quip at 'some fashionable French philosopher', also because of my own engagement with work from this region. I am not sure whether 'French' is the problem - which would perhaps disqualify Foucault, Derrida and Levinas (albeit that the latter two were not born in France) but would keep other Continental philosophers such as Agamben, Habermas and Kierkegaard in the picture or whether it is the 'fashionable' he opposes to - which might suggest that philosophers of education should only engage with a philosopher's ideas if they have good reasons for doing so. Yet, this then raises the question as to what counts as a good reason, and how dependent this is on the particular philosophical tradition within which one is working. But this is only a minor issue, not in the least because the question as to what counts as good philosophy - and even the question what counts as philosophy at all - has been an ongoing bone of contention within the tradition of philosophy (and the pre-occupation with this question may well be one of the few characteristics that holds the field together). White is actually quite careful about these matters, as he refers consistently to 
'philosophy as we know it today' rather than relying on some abstract and a-temporal conception of what philosophy is or ought to be - although there is still the question about the reference of the 'we' in this statement, an issue to which I will return below.

In this article, I would like to take up one of the themes from White's paper, namely, that of the relationship between philosophy and education and, perhaps more specifically, that of the relationship between philosophical scholarship and educational scholarship. With regard to this, White distinguishes between two options: that of philosophy of education as a form of applied philosophy or, as he puts it, following Siegel, a 'branch' of philosophy, and that of philosophy of education located within what White refers to as 'the world of education'. He refers to the latter as 'our own world', thus indicating his preference for this as the place where philosophers of education should conduct their work. If I see it correctly, White's argument is first and foremost an argument about the location of philosophy of education. After all, the difference he highlights is not between two different ways of 'doing' philosophy of education, but between philosophy of education based in philosophy departments and philosophy of education based in schools of education. ${ }^{1}$

The distinction White is making can therefore be understood as a social - or if one wishes, sociological - distinction, as it appears that what makes someone count as a philosopher has, in White's eyes, to do with where they conduct their work, not with what they do, and probably also not with the education or qualifications they have. White says very little about the latter actually, which raises the question whether in order to be a philosopher or, for that matter, a philosopher of education in White's conception, one actually needs to have a degree in philosophy. Nonetheless, he has little difficulty in identifying David Archard, John Haldane, Stephen Law, Michael Luntley and Richard Norman as real philosophers working in the United Kingdom and, for an example from the United States, Harry Brighouse as having 'a distinguished foot in both camps' - the camp-metaphor providing a further indication that the distinction White is after is one of location.

While I agree with White that the proper location for any philosophically informed form of educational scholarship (I will explain this particular phrase below) is in 'the world of education', I have some questions about the idea that this should occur only or necessarily in the form of philosophy of education. In this sense, it is remarkable that White nowhere in his essay raises any questions about the notion of philosophy of education itself. In what follows, I will explore a different way of connecting philosophy and education. I will do this both intellectually and sociologically, that is, both in terms of the 'forms' of philosophically informed scholarship and in terms of its social location. While I do not wish to contest philosophy of education as it exists today in a number of (mainly English-speaking) countries, I will argue that to conceive of the relationship differently is perhaps the only way to overcome the ongoing debate about the proper location of philosophy of education. The different way of connecting philosophy and education not only points in the direction of a mode of intellectual work that might be more relevant for the world of education itself. Conceiving of the relationship differently may perhaps also free philosophically informed educational scholarship from the 'discipline' of philosophy - by which I not only have in mind philosophy as an academic discipline but also mean to refer to attempts at disciplining and reigning in such scholarship from the side 
of those working in departments of philosophy. It is only then, so I wish to suggest, that philosophically informed educational scholarship can be taken seriously in its own terms, rather than as always being treated as a derivative of 'real' philosophy. ${ }^{2}$

\section{On the pre-history and history of the idea of philosophy of education}

The history of philosophy of education has two distinctive though not entirely disconnected lines. One - to which I will refer to as the 'pre-history' of philosophy of education - concerns the ongoing interest philosophers have had in educational matters. Within the canon of Western philosophy, this goes at least back to Plato and Plato's Socrates, with further contributions from some of the biggest names in Western philosophy, such as Locke, Rousseau and Kant. I would also include Dewey here because, except for a short period in Chicago, he worked for most of his career as a philosopher in philosophy departments. That philosophers are interested in education should not come as a surprise since education, be it in the family, in schools or in society, is an intriguing phenomenon that, as White also shows, raises important questions in relation to domains where philosophers have, over the centuries, developed and claimed expertise. John Dewey has even argued that education can be seen as a 'laboratory in which philosophical distinctions become concrete and tested' (Dewey, 1966 [1916]: 329), which led him to the suggestion that philosophy may even be defined as 'the general theory of education' (Dewey, 1966 [1916]: 328, emphasis in original). What characterises such work intellectually is that it is focused on asking philosophical questions about education. This is why the label 'philosophy of education' is entirely appropriate for this work.

The history of the other manifestation of philosophy of education, the one located within schools and departments of education, is a bit more complicated, as it not only has to do with the question how philosophy of education ended up in such schools and departments of education but also with the wider question of the formation of education as an academic field within which philosophy of education found its place. As I have shown elsewhere in more detail (see particularly Biesta, 2011, 2012), the idea of philosophy of education is part of the way in which education as a multidisciplinary academic field developed in the twentieth century in English-speaking countries and regions such as the United Kingdom and North America (see also McCulloch, 2002; Richardson, 2002; Tibble, 1966). When we take Britain, and more specifically England, as an example below I will add some detail about developments in the United States - it is important to see that education as an academic field developed in the context of the education of teachers. While teacher education in England was initially strongly practice based, some more theoretical strands began to emerge towards the end of the nineteenth and the beginning of the twentieth century. These included the study of method, the history of education and, increasingly, educational psychology, a field which became more firmly established as a subject of study in the 1920s. Sociology and philosophy only gained prominence from the late 1950s/early 1960s onwards (see also McCulloch, 2002).

In England - but a similar patterns can be found in many other countries - there were, until the Second World War, two routes into teaching (see Hirst, 2008, whose account I follow here). One was to study for a bachelor's degree in a relevant curriculum subject 
at a university and then take a 1-year course at a university Department of Education for the Postgraduate Certificate in Education. The other was to train at a free-standing College of Education for 3 years, taking a combined course of academic studies in a curriculum subject plus practical training, leading to the College's own Certification in Education. In the decades after the Second World War, two important developments took place. The McNair Report (Board of Education, 1944) recommended that every College of Education should be brought under the supervision of a local university. For this purpose, each major university established an Institute of Education for the colleges under its area. The Robbins Report (Committee on Higher Education, 1963), which focused on the whole provision of Higher Education in the United Kingdom, recommended that all the Colleges of Education should redevelop their courses in arrangement with local universities so that all students taking 3 years would be awarded an Ordinary Bachelor of Education degree and students taking a fourth year would go on to receive an Honours Bachelor of Education degree. The aim was to eventually create an all graduate profession of school teachers. As a result of this, teacher education became strongly connected to and eventually (almost) fully integrated into the university sector - albeit not in all cases wholeheartedly (on the detail, see Richardson, 2002: 16).

These developments, and also the very practical need to design curricula for the new university-based teacher education programmes, inevitably raised questions about the academic status and identity of teacher education and of education as an academic 'field' more generally. While in principle the focus could have been on innovative ways of developing teacher education as a form of professional education, the road taken was one in which the 'academic, university interest' (Richardson, 2002: 18) prevailed. According to Richardson (2002), RS Peters played a key role in this particular development. His inaugural lecture as professor of philosophy of education at the University of London Institute of Education (see also Peters, 1963) - which Richardson characterises as a 'pre-emptive strike' (Richardson, 2002: 18) - was given 6 weeks after the publication of the Robbins Report. Richardson suggests that by focusing on the theme of education as initiation, Peters was able to discuss 'both the education of children and of those intending to teach them' (p. 18). With regard to the latter, Peters defended the view that conceptual clarification within educational studies was 'pre-eminently the task of a philosopher of education' and this, as Richardson shows, led him to propose 'that the field should comprise a balance among the disciplinary perspectives competing for attention: economics, sociology and psychology' (p. 18). Moreover, 'to ensure teachers escaped the threat of "conceptual blight", philosophers would need to adjudicate among these disciplines in order to establish the basis of a coherent concept of education' (p. 18).

Peters' outline for a possible structure for the field of educational studies was met with approval by officials from the government Department of Education and Science, and by CJ Gill, the then Chief Inspector responsible for the education of teachers (see Richardson, 2002: 18). This led to the convening by the Department of a closed seminar held in Hull in 1964 at which selected professors of education from England, led by Peters and with guidance from Gill, 'hammered out the structure within which educational studies in England and Wales would expand and develop over the coming two decades' (p. 18). In the event, economics was relegated in favour of history 'which now 
joined philosophy, psychology and sociology in a quarter of "foundation disciplines" defining the scope and nature of teaching and much research in the field' (p. 18).

In one sense, one might say that it was this set of events that led to the particular construction of the academic field of education in the United Kingdom, conceived as an interdisciplinary field based on input from a number of academic disciplines with, at least in the eyes of Peters, philosophy positioned as the overall adjudicator. Two things stand out. One is that the academic field is organised around education as an object of study. The second is that the study of education relies on the intellectual input from a number of existing and (at the time) established academic disciplines, philosophy being one of them. In this way, then, philosophy of education ended up in institutes or, with designations that would become more popular later, schools or departments of education. We could even say that in one and the same 'move', the idea of philosophy of education was conceived and institutionalised.

While Peters' activities played an important role, it is too much to claim that Peters actually constructed the field single-handedly. As Brian Simon has argued, Peters 'simply crystallized contemporary developments in the field' (Simon, quoted in Richardson, 2002: 18). This doesn't do away with the fact that Peters apparently was able to seize the opportunity to consolidate these developments. It also doesn't do away with the fact that this consolidation has been hugely influential in the further development of education as an academic field in the United Kingdom and other English-speaking countries, not only in the years since its inception but also, at least according to some (see Furlong and Lawn, 2010), as a blueprint for the foreseeable future. Although it is likely that Peters consolidated developments that were already 'in the air', one intriguing question is what inspired Peters to argue for this particular way of configuring the field. For part of the answer, we need to go back in time a little and move to the other side of the Atlantic.

\section{'Freeing teachers from domination by educationists': The Harvard model}

The developments in the field of teacher education in the United States have largely followed the same patterns as what happened in Britain. As Waks (2008) makes clear, teacher education before the mid-twentieth century mainly took place in normal schools or teacher colleges, but rarely in the university. In the 1940s, however, normal schools were converted into teachers colleges, and in the $1960 \mathrm{~s}$, these were converted into state universities. For the first time, then, 'school teachers required a proper university education' (Waks, 2008: 1). Waks credits James Conant, president of Harvard, with envisioning 'a new kind of university-based school of education, drawing scholars from mainstream academic disciplines such as history, sociology, psychology and philosophy, to teach prospective teachers, conduct educational research, and train future educational scholars' (p. 1).

Funded by a grant from the Rockefeller Foundation, these ideas were put into practice through the appointment, in 1952, of the philosopher Israel Scheffler and the historian Bernard Bailyn to Harvard's Graduate School of Education as part of a deliberate attempt to introduce "young scholars ... who had not been trained in the field of Education but in the Liberal Arts subjects' (Scheffler, 2008: xi). Scheffler not only started to connect 
analytic philosophy with education, thus inaugurating the development of an 'analytical revolution in the philosophy of education' (Waks, 2008). He also lays claim to having turned Richard Peters - who, before he had met Scheffler, conceived of himself as a philosopher of psychology and of political theory - into a philosopher of education (for the details of this, see Scheffler, 2008). Scheffler was not only instrumental in getting Peters to Harvard, where he could gain first-hand experience of their model of teacher education. He also provided active support for Peters' candidacy for the Chair of Philosophy ${ }^{3}$ at the Institute of Education in London which had become vacant after the departure of Louis Arnaud Reid, and to which Peters was eventually appointed.

Scheffler's account sheds light on at least one possible source of inspiration for Peters' own views about the configuration of the academic field of education. Yet, the story has a wider significance than just what happened at Harvard in the 1950s, because about a decade later, the very same James Conant led a 2-year study on teacher education financed by the Carnegie Corporation and resulting in a report, The Education of American Teachers (Conant, 1963). This influential report did indeed put forward a case for the configuration of the education of teachers as based upon the input from 'proper' academic disciplines. As Waks (2008) puts it, the Conant report concluded that 'effective teaching of academic content in education could only come from properly trained professors bringing to bear on educational topics the best, most current methods from wellestablished academic disciplines' (p. 3). And the point here was not only to bring in such a disciplinary perspective on the study of education but at the very same time 'to free teachers from domination by educationists' (p. 3).

\section{The road not taken: Education as an academic discipline}

While for many familiar with the construction of the academic field of education in the English-speaking world the foregoing reconstruction only adds historical detail to what they are most likely to see as the way in which things are and probably ought to be, a look towards the East, that is to the German-speaking academic world, reveals a very different picture. Here, education did not become a multidisciplinary field in which education provides the object of study and 'proper' academic disciplines provide intellectual content and focus. Rather, we find a situation where education developed as an academic discipline in its own right, on a par with, rather than subordinated to psychology, sociology, history and philosophy (see Horn, 2003; Thiersch et al., 1978). One main reason for this different configuration is that it did not develop in the context of the incorporation of teacher education into the university, but emerged from a much older interest in education as a 'phenomenon', so to speak, where this phenomenon was first and foremost seen as having to do with the formation of the individual - and in the religious traditions this emerged from: the formation of the individual's soul and virtuousness - in relation to and in interaction with culture and society (see Oelkers, 2001; also Biesta, 2011).

Out of this emerged an academic tradition that was first and foremost interested in the question of the individual's freedom. It thus saw education as more than just a process of adaptation and socialisation, but rather as a process of emancipation. While there were important precursors of this particular tradition - in addition to Rousseau, we can think here, for example, of Pestalozzi (1746-1827) and Froebel (1782-1852) - the actual 
establishment of education as an academic discipline took shape towards the end of the nineteenth and the beginning of the twentieth century. This happened first of all through the work of Wilhelm Dilthey, who made a case for education as a Geisteswissenschaft (a science of culture rather than of nature). This line of thought was further developed by scholars such as Hermann Nohl, Eduard Spranger, Otto-Friedrich Bollnow, Wilhelm Flitner, Erich Weniger and Theodor Litt, who played a key role in establishing geisteswissenschaftliche Pädagogik at German universities, and whose conception of education as an academic discipline also impacted on the establishment of the field in other countries such as, for example, the Netherlands or Finland.

The fact that education established itself as an academic discipline in its own right did not mean that it was not in 'conversation' with other academic disciplines, but rather than to suggest that those academic disciplines were essential in order to do any academic work at all, those working in the Continental-German tradition saw insights emerging from other disciplines, including philosophy, as possible resources for what they saw as their key task, which was to develop educational forms of theory and theorising. The idea of education as a discipline in its own right, with its own forms of theory and theorising, not only distinguishes the way in which the field was established in the German-speaking context from how it developed in English-speaking countries. In the English-speaking context, this very idea - that is, that there can be and ought to be distinctively educational forms of theory and theorising, and that such forms of theory and theorising are essential to the discipline of education - was actually explicitly rejected. In an essay from 1966, Paul Hirst (1966) did, for example, explicitly state that education is not and cannot be 'an autonomous discipline' because it does not generate 'some unique form of understanding about education' in addition to what is already generated by what he referred to as 'the fundamental disciplines' (p. 51). ${ }^{4}$ The position was stated even more explicitly a few years later by JW Tibble (1971) when he wrote,

It is clear that 'education' is a field subject, not a basic discipline; there is no distinctively 'educational' way of thinking; in studying education one is using psychological or historical or sociological or philosophical ways of thinking to throw light on some problem in the field of human learning. (p. 16)

Tibble's statement reveals another important difference between the two constructions of the field in that in the English-speaking tradition the field is organised around an object of study - which is why Tibble uses the term 'field subject' - whereas in the Continental-German tradition it is organised around a particular educational interest, namely, the interest in the emancipation of the child and student. In this sense, we might call the first construction 'object-ive' in the literal sense of the word, and the second as literally 'interest-ed' (Biesta, 2011).

\section{Discussion: Connecting philosophy and education differently}

In this article, I have explored a relatively minor but nonetheless persistent issue within the field of philosophy of education, which has to do with the question whether its 
proper location is in departments of philosophy or in departments of education. With White, I believe that this kind of scholarship should indeed be located in departments, schools or institutes of education. But whereas White argues that what should be located here is an activity called 'philosophy of education', I have suggested that the very idea of 'philosophy of education' needs to be brought into the discussion as well. One reason for this has to do with the fact that the idea of 'philosophy of education' is not neutral or universal, but comes out of a very specific history and has a place in a very specific construction of education as an academic field. By comparing developments in the English-speaking world with those in the German-speaking world, I have shown that the academic field of education can be and has been constructed differently. More importantly, in this different construction, we can find a very different 'mode' of engagement between philosophical and educational scholarship. The difference between these two 'modes' - and this is the second reason why the idea of philosophy of education itself needs to be challenged - can be summarised by saying that in the English-speaking tradition, the focus is on asking philosophical questions about education, whereas in the German/Continental tradition, philosophy is one of the resources for asking and answering educational questions about education. This is not to suggest that it is not meaningful to ask philosophical questions about education, but to highlight that these are not the only intellectually relevant or interesting questions that can be asked about education. It is also not to suggest that there is total agreement within the philosophical community about what it means to ask philosophical questions or in the educational communication about what it means to ask educational questions. These discussions are ongoing but they take place within distinctively different academic communities. ${ }^{5}$

The difference between these two ways of connecting philosophy and education is significant for a number of reasons. If the point of philosophically informed educational scholarship is to ask philosophical questions about education (and thus generate philosophical answers to those questions), then I would be inclined to say that this work needs to live up to the standards of the philosophical academic community which means that, intellectually but not necessarily with regard to its social location, it belongs to philosophy. This shows, so I wish to suggest, why White's argument is not really able to resolve the discussion, because even if philosophy of education is being conducted in schools of education, it must, as long as it conceives of itself as philosophical scholarship, live up to the standards of philosophy - by which I am, of course, not suggesting that those standards are fixed or even clear (the 'boundary work' is ongoing; see Gieryn, 1983), but it would mean that philosophers of education take discussions about what counts as philosophy as their point of reference. Then, however, philosophy of education remains a halfway house that may struggle to be taken seriously either by philosophers - and I have indicated some aspects of this problem, as has White - or by educationists - about which I have said less, but would like to refer to the marginal status that philosophy of education tends to have within the field of educational research, despite the ongoing efforts of many working in philosophy of education to establish such connections (see, for example, the 'IMPACT' series of publications from the Philosophy of Education Society of Great Britain; http:/www.philosophy-of-education.org/impact/impact.asp - last accessed 29 September 2013). 
It is here that we find one of the main attractions of the way in which philosophy plays a role in the German/Continental academic field of education where philosophy is one of the resources for conducting theoretical - and for that matter also empirical - research and scholarship in education. The fact that such work is located within schools and departments of education is obvious. But what is more interesting is that, at least in principle, it has a clearer intellectual location since it is a form of educational scholarship that needs to live up to the standards in that discipline, rather than to the standards of philosophy. (What those standards are is, again, a matter of ongoing discussion, but my point is that the 'reference community' for this is the community of educational researchers and scholars, not the community of philosophers.) This is not to suggest, of course, that the ways in which philosophy is being used as a resource in such work can be oblivious of discussions in the field of philosophy - and here, I do think that there is a large body of work that engages in far too simplistic ways with philosophy in a kind of ill-informed 'pick-and-mix' approach - but it does not mean that the work belongs to the discipline of philosophy (again in the double sense of the word 'discipline'.

I do not have the intention to challenge or criticise philosophy of education as it exists in the English-speaking world, because it simply is what it is - and one could even say that within its own context and history, the idea of philosophy of education is entirely rational. But what I have tried to do in response to White, is to show a different connection between philosophy and education, being practised in a different location and by a different 'we' - to come back to White's use of this word. What is interesting about this different connection is that, unlike what I see White doing, it provides a way out of the ongoing discussion about the proper location of philosophy of education. This also means - and this is reflected in the title of my article, partly tongue-in-cheek - that the discussion about the proper location of philosophy of education cannot be resolved within the terms of the idea of philosophy of education. Whether the other way to connect philosophy and education is a viable option for the English-speaking world remains to be seen. But it is at least important to make this option more visible, as it seems to be off the radar of White and, if I am correct, many others in the English-speaking philosophy of education world.

\section{Funding}

This research received no specific grant from any funding agency in the public, commercial or not-for-profit sectors.

\section{Notes}

1. Note that the notion of 'school of education' is a rather British construct, not known or used widely in many other countries.

2. That this is not just an intellectual matter but one with real implications can, for example, be seen in the way in which the Spencer Foundation has recently been promoting philosophy of education, not by directly supporting the work of those who identify themselves as philosophers of education, but rather by trying to bring 'real' philosophers in.

3. Scheffler refers to the chair as a 'chair in philosophy,' whereas some other sources name it as a 'chair in philosophy of education.' I have not been able to verify the actual designation. 
4. In the United States, Scheffler has provided a similar argument why education is not and should not be conceived of as a discipline (see Scheffler, 1973, chapter 4: Is education a discipline?).

5. Given that only very little Continental work has been translated into English, it may be difficult for English-speaking readers to get an idea of what such work might look like. From this angle, it is fortunate that one of the key texts by the German educationalist Klaus Mollenhauer has become available in English translation (see Mollenhauer, 2013). For those who have access to the French language, the work of Philippe Meirieu provides an excellent example of what I see as philosophically informed educational scholarship (see, for example, Meirieu's website: http://www.meirieu.com). Another extremely helpful contribution is Siljander et al. (2012). I also refer the reader to Biesta et al. (2014).

\section{References}

Biesta GJJ (2011) Disciplines and theory in the academic study of education: A comparative analysis of the Anglo-American and Continental construction of the field. Pedagogy, Culture \& Society 19(2): 175-192.

Biesta GJJ (2012) Wanted, dead or alive: Educationalists. On the need for academic bilingualism in education. In: C Aubry, M Geiss, V Magyar-Haas, et al. (eds) Positionierungen. Zum Verhältnis von Wissenschaft, Pädagogik und Politik, pp. 20-33. Weinheim: Beltz Verlag.

Biesta GJJ, Allan J and Edwards RG (eds) (2014) Making a Difference in Theory: The Theory Question in Education and the Education Question in Theory. London; New York: Routledge.

Board of Education (1944) Teachers and Youth Leaders (McNair Report). London: HMSO.

Committee on Higher Education (1963) Higher Education: Report of the Committee (Robbins Report). London: HMSO.

Conant JB (1963) The Education of American Teachers. New York: McGraw-Hill.

Dewey J (1966 [1916]) Democracy and Education. New York: The Free Press.

Furlong J and Lawn M (2010) Disciplines of Education: Their Role in the Future of Education Research. London: Routledge.

Gieryn TF (1983) Boundary-work and the demarcation of science from non-science: Strains and interests in professional ideologies of scientists. American Sociological Review 48(6): $781-795$.

Hirst PH (1966) Educational theory. In: JW Tibbe (ed.) The Study of Education, pp. 29-58. London: Routledge and Kegan Paul.

Hirst PH (2008) Philosophy of education in the UK: The institutional context. In: LJ Waks (ed.) Leaders in Philosophy of Education: Intellectual Self Portraits, pp. 305-310. Rotterdam: Sense Publishers.

Horn KP (2003) Erziehungswissenschaft in Deutschland im 20. Jahrhundert. Bad Heilbrunn: Julia Klinkhardt.

McCulloch G (2002) Disciplines contributing to education? Educational studies and the disciplines. British Journal of Educational Studies 50(1): 100-110.

Mollenhauer K (2013) Forgotten Connections: On Culture and Upbringing. London; New York: Routledge.

Oelkers J (2001) Einführung in die Theorie der Erziehung. Weinheim; Basel: Beltz.

Peters RS (1963) Education as initiation. In: P Gordon (ed.) The Study of Education, vol. 1, pp. 273-299. London: Woburn.

Richardson W (2002) Educational studies in the United Kingdom, 1940-2002. British Journal of Educational Studies 50(1): 3-56.

Scheffler I (1973) Reason and Teaching. London: Routledge and Kegan Paul. 
Scheffler I (2008) Foreword. In: LJ Waks (ed.) Leaders in Philosophy of Education: Intellectual Self Portraits, pp. xi-xvi. Rotterdam: Sense Publishers.

Siegel H (ed) (2009) The Oxford Handbook of Philosophy of Education. Oxford: Oxford University Press.

Siljander P, Kivelä A and Sutinen A (eds) (2012) Theories of 'Bildung' and Growth: Connections and Controversies between Continental Educational Thinking and American Pragmatism. Rotterdam; Boston, MA; Taipei, Taiwan: Sense Publishers.

Thiersch H, Ruprecht H and Herrmann U (1978) Die Entwicklung der Erziehungswissenschaft. Munchen: Juventa.

Tibble JW (1966) The development of the study of education. In: JW Tibble (ed.) The Study of Education, pp. 1-28. London: Routledge and Kegan Paul.

Tibble JW (1971) The development of the study of education. In: JW Tibble (ed.) An Introduction to the Study of Education, pp. 5-17. London: Routledge and Kegan Paul.

Waks LJ (2008) Introduction. In: LJ Waks (ed.) Leaders in Philosophy of Education: Intellectual Self Portraits, pp. 1-13. Rotterdam: Sense Publishers.

\section{Author biography}

Gert Biesta (http://www.gertbiesta.com) is Professor of Educational Theory and Policy at the Institute of Education and Society, University of Luxembourg. He is also Editor-in-Chief of Studies in Philosophy and Education. He has a degree in education from Leiden University and a degree in philosophy from Erasmus University Rotterdam, and is a former Spencer Postdoc with the National Academy of Education, USA. He has published widely on the theory and philosophy of education and educational and social research, with a particular focus on questions of democracy and democratisation. He has a particular interest in the development of education as an academic field or discipline. In addition to his theoretical and philosophical work, he has also participated extensively in empirical educational research. Recent books include Good Education in an Age of Measurement (Paradigm Publishers 2010) and The Beautiful Risk of Education (Paradigm Publishers 2014). 